\title{
Implementation of 5M Strategy in Distance Learning of English Language Teaching (ELT)
}

\author{
Madya Giri Aditama, Prasetyawan Aji Sugiharto
}

English Education Department, STKIP Muhammadiyah Batang, Indonesia

madya.aditama@gmail.com, asprasetyawan@gmail.com

\begin{tabular}{ll}
\hline Article History & Received : July $9^{\text {th }} 2021$ \\
& Revision : August $17^{\text {th }} 2021$ \\
& Publication : Sept $30^{\text {th }} 2021$ \\
\hline
\end{tabular}

\begin{abstract}
English Language Teaching (ELT) in Indonesia faced crucial time during Covid-19 pandemic period. In the distance learning process of ELT, teachers face difficulties in doing teaching learning process. 5M strategy helped teachers to maximize their relationship with students and parents in order to create an essential teaching learning activity, the objectives of this study are "Classifying the 5M strategy applied by the teacher in Distance Learning of ELT" and "Describing the example method of each strategy used by teacher in Distance Learning of ELT process". The study employed qualitative approach in which the researchers used questionnaire and interview to collect the data. The participants were 20 high school English teachers in Batang region. From the study, it was found that the teachers applied 5M strategy in their learning process. The resuls shown that there are 16 teachers (80\%) applied Memanusiakan Hubungan (Humanize Relationships) strategy, only 8 teachers (40\%) applied Memahami Konsep (Understanding Concepts) strategy, 16 teachers (80\%) considered Membangun Keberlanjutan (Building Sustainability) strategy in their teaching, 17 teachers (85\%) presented Memilih Tantangan (Choosing Challenges strategy, and all 20 teachers (100\%) were able to apply Memberdayakan Konteks (Empowering Context) strategy. This study also reveals some unique and new teaching methods applied in each strategy by the teachers.
\end{abstract}

Keywords: 5M Strategy, Distance Learning, ELT.

\section{INTRODUCTION}

Education is a mandatory need which every citizen has especially students. The Indonesian law also stated that every citizen has the same position in getting education. The "Merdeka Belajar" Curriculum recently launched by the Ministry of Education and Culture provides a clear discourse on the essence of freedom of thought and freedom of learning not only for students but also for teachers. The concept of independence and freedom in learning that was just about to begin was immediately hampered by the outbreak of the Covid-19 pandemic in Indonesia which affected every sector of people's lives. In the education sector itself, the Covid- 
19 pandemic has an impact on system changes and learning activities that require the application of Distance Learning. Now it is a challenge for educators and students who inevitably have to be ready to face the existing online learning (Tîrziu, A. M., \& Vrabie, 2015). Differences in face-to-face learning in Distance Learning gave different effect on the quality of student learning (Karwati, 2014). In the process of activities, where teachers and students were required to carry out teaching and learning activities with all limitations so that not all systems and learning methods in every subject can run well. This limitation caused the emergence of obstacles in Distance Learning activities as expressed by Rusman, et al (2013:271), namely: "access to learning often occurs problems for learners".

These limitations in learning are experienced in all levels of education and in all subject areas. Especially in English which has 4 basic skills that students must master, they are Speaking, Listening, Reading, and Writing, it requires English teachers to think creatively and innovatively in preparing teaching methods that are in accordance with the distance learning situation and able to cover all competencies in English. Zaw (2019) also stated that keeping students awake and interested during an ELT period is a little difficult for the classroom practitioner. Using authentic materials can effectively engage students' active participation in class. Teachers needed to upgrade their ability to use technology and select appropriate materials (Laeli \& Oktarini, 2021).

The 5M strategy is a strategy formulated to conform the essence of "Merdeka Belajar" concept. Shihab (2018) formulated a 5M strategy in learning which was described as: (1) Memanusiakan Hubungan (Humanize Relationships), (2) Memahami Konsep (Understanding Concepts), (3) Membangun Keberlanjutan (Building Sustainability), (4) Memilih Tantangan (Choosing Challenges), (5) Memberdayakan Konteks (Empowering Context). The goal of this strategy is to encourage parent, teacher and student collaboration to empower learning and ensure students have a meaningful, challenging learning experience that suits their abilities and needs. Based on the description that has been stated, the writers are interested in conducting research which discoved the application of $5 \mathrm{M}$ strategy in Distance Learning activity.

\section{Distance Learning}

According to Prawiyogi, A G (2020), Distance Learning was learning using a medium that allows interaction between teachers and learners. In Distance Learning activities between teachers and learners do not do face-to-face learning activities directly, which is made possible through this Distance Learning activity is teachers and students are in different places, even can be separated by very long distances. Distance Learning also known as online learning and e-learning (electronic learning). Based on technological and organizational aspects, Moore, M., \& Kearsley, (2012:2) defined that Distance Learning is teaching and planned 
learning where teaching takes place as usual but occurs in different places, requiring communication through technology and certain forums. Viewed from the distance aspect, Finch, D., \& Jacobs, (2012:546) defined Distance Learning as a form of teaching and learning activity in which students and instructors are separated geographically and by time. In accordance with the Indonesia Minister of Education and Culture Circular number 4 of 2020 (Mendikbud RI., 2020) regarding the Study from Home Policy, which is essentially through distance learning, providing meaningful learning experiences, learning activities and assignments from home learning can vary between students including considering access gaps or home learning facilities, evidence or products of home learning activities given qualitative and useful feedback from the teacher. Distance Learning must remain implemented with a strategy which is able to minimize physical contact between students and other students, or between students and teachers (Firman, \& Rahayu, 2020). Distance learning process should be able to accommodate students' learning needs to develop students' talents and interests according to their education level (Basar, 2021).

Pramana (2021) studied about Distance Learning in Primary Schools During The Covid-19 Pandemic in Indonesia: Challenges, Solutions and Projections. His study showed that the impact of Covid-19 on implementation of online learning in elementary schools in Indonesia can be implemented quite well. The impact of Covid-19 on the implementation of distance can be carried out quite well if there is a collaboration between teachers, students, and parents in learning at home. Abidin, et al (2020) said the learning process during Covid19 pandemic were quite effective although there were some obstacles in conducting online learning, such as technical aspect and economic aspect of the students. Technology usage in online learning is crucial. Maintaining students' engagement in online learning by using digital media is important. By combining digital literacy in English language learning, it can maintained students' ability in English (Aditama, M G., 2020).

Apart from these factors, another obstacle interfered with the learning process is the availability of data packages. The smoothness of the learning process was influenced by some requirements which should be existed. The availability of a good internet network, sufficient data packages, and the ownership of a cellphone or laptop for each student (Rusmiati, A. R., et al (2020). The availability of personal gadget by the students is important. Aditama, M G. \& Sugiharto (2021) stated that using gadget for students' individual practice influenced the frequencies of students' learning history. Combining digital tools as learning media required both students and teacher mastery in using it. In fact, not a few teachers did not understand information and communication technology, coupled with an unstable internet connection (Zaharah, Z., \& Kirilova, 2020). The use of information technology had a very important role in the 
implementation of distance learning in the midst of the covid19 virus pandemic (Pakpahan, R. \& Fitriani, 2020).

\section{M Strategy}

The $5 \mathrm{M}$ strategy is a strategy formulated to conform to the session concept of the Merdeka Belajar concept. Shihab (2018) formulated a 5M strategy in learning which is described as follows:

a. Memanusiakan Hubungan (Humanizing Relationships)

Learning practices that are based on child orientation based on positive relationships that understand each other between teachers, students and parents.

b. Memahami Konsep (Understand the Concept)

Learning practices which guide students not only mastering content but also mastering deep understanding of concepts that can be applied in various contexts.

c. Membangun Keberlanjutan (Building Sustainability)

Learning practices that guide students through a directed and continuous route of learning experiences through feedback and sharing of good practices.

d. Memilih Tantangan (Choosing a Challenge)

Learning practices that guide students to master skills through a process tiered with a choice of meaningful challenges

e. Memberdayakan Konteks (Empowering Context)

Learning Practices that guide students involve resources and opportunities in the community as learning resources as well as opportunities to contribute to change.

The goal of this strategy is to encourage parent, teacher and student collaboration to empower learning and ensure students have a meaningful, challenging learning experience that suits their abilities and needs.

From several studies on Distance Learning and online learning that have been carried out by some of these researchers, no one has researched English learning in the Merdeka Belajar Curriculum, so it becomes a reference to enrich the research discussion, and provides an overview of the differences with the research that is being carried out. Based on the phenomena mentioned, the research objectives guide in this study are: (1) Classifying the 5M strategy applied by the teacher in Distance Learning of ELT and (2) Describing the example method of each strategy used by teacher in Distance Learning of ELT process.

\section{METHOD}

This is descriptive qualitative reasearch. The data consist of 20 questionnaire and interview results of Senior High School level English teachers in 
Batang Regency. The data were collected through documentation method by using content analysis technique and interviewed with English Teachers of Senior High School level in Batang regency who applied 5M strategy in distance learning of ELT process. The data validity in this study used triangulation of data sources by using document of questionnaire and informants of interview records with the teachers, also triangulation of data collecting technique, which the researcher used are documentation and interview.

The data were analyzed by content analysis technique using observation method, a total 20 data were observed to find out the implementation of 5M strategy in Distance Learning of ELT by following the steps: (1) Classifying the 5M strategy applied by teacher in Distance Learning of ELT; (2) Describing the example method of each strategy used by teacher in Distance Learning of ELT process.

\section{RESULTS AND DISCUSSION}

\section{M Strategy Applied by Teacher in Distance Learning of ELT Process.}

Based on the questionnaire and Focus Group Discussion, it was found that not every teacher able to apply all strategies of 5M strategy in their distance learning activity. The classification in using each strategy is delivered as follow:

Table 1. Application of 5M Strategy by Teacher

\begin{tabular}{|c|c|c|c|}
\hline No & 5M Strategy & $\begin{array}{c}\text { Number of } \\
\text { Teacher }\end{array}$ & Percentage \\
\hline 1 & $\begin{array}{l}\text { Memanusiakan Hubungan (Humanizing } \\
\text { Relationships) }\end{array}$ & 16 & $80 \%$ \\
\hline 2 & $\begin{array}{l}\text { Memahami Konsep (Understand the } \\
\text { Concept) }\end{array}$ & 8 & $40 \%$ \\
\hline 3 & $\begin{array}{lll}\text { Membangun Keberlanjutan } & \text { (Building } \\
\text { Sustainability) } & & \\
\end{array}$ & 16 & $80 \%$ \\
\hline 4 & Memilih Tantangan (Choosing a Challenge) & 17 & $85 \%$ \\
\hline 5 & $\begin{array}{l}\text { Memberdayakan Konteks (Empowering } \\
\text { Context) }\end{array}$ & 20 & $100 \%$ \\
\hline
\end{tabular}

After classifying the data source based on the application of 5M strategy used by teacher in Distance Learning of ELT. It was found that there are 16 teachers $(80 \%)$ applied $1^{\text {st }}$ strategy, only 8 teachers (40\%) applied $2^{\text {nd }}$ strategy, 16 teachers $(80 \%)$ considered $3^{\text {rd }}$ strategy in their teaching, 17 teachers $(85 \%)$ presented 4 th strategy, and all 20 teachers $(100 \%)$ applied $5^{\text {th }}$ strategy in their teaching learning method. Based on the data result, the most dominant strategy which are able to be applied by the teachers in their distance learning process was Memberdayakan Konteks (Empowering Context). 


\section{Example Method of Each Strategy used by Teacher in Distance Learning of ELT Process.}

Based on the analysis of quesionnaire and interview results, it shown that there were some dominant strategies applied by teachers in their distance learning process. Each teacher gave such unique example of teaching learning activity in the class. The learning activities of each strategy were showed as follows:

a. Memanusiakan Hubungan (Humanizing Relationships)

This strategy is oriented in the understanding relationship between teachers, students and parents. Based on the data result got the example of the strategy applicatoin as follows:

Data $07 / 1$

"Melakukan asesmen diagnosis dengan menanyakan tentang profil siswa dan orang tua"

[Conducting a diagnostic assessment by asking about the profile of students and parents]

This statement also applied by other teacher who use the same method to conduct information about students background, as follows:

Data 05/1

"Melakukan assessmen diagnostik di awal pembelajaran. Melakukan pendekatan personal dalam pembelajaran melalui chat WA maupun platform lain. Menanyakan permasalahan yang dihadapi murid. Membangun komunikasi dengan orang tua. Menggunakan ice breaking dalam kelas"

[Conducting diagnostic assessment at the beginning of the lesson. Take a personal approach to learning through Whatsapp chat and other platforms. Ask about problems faced by students. Build communication with parents. Using ice breaking in the class.]

Another method used by teacher to undertand students was using profile mapping, like as follows:

Data $01 / 1$

"saya memetakan profil siswa di awal semester"

[I mapped students' profiles at the beginning of the semester]

Based on the examples of the data, it can be seen that teachers have similar method in understanding the relationship to the students and parents. Using profile mapping and diagnostic assessments are some example methods appled. Lee, Y. W., \& Sawaki (2009) defined Cognitive Diagnostic Assessment (CDA) as a set of cognitively grounded, diagnostic procedures attempted to pinpoint students' strengths and weaknesses in relation to their knowledge structures and processing skills (referred to as attributes) in the target domain. It is also supported by Lee, (2015) who stated that information generated from CDA could be used to help promote students' learning and guide further instruction.

By applying this strategy, teacher will be able to conduct good relationship to the students and by knowing students' profile and background, teacher can design a teaching learning method which suitable to the students' ability and environment. 


\section{b. Memahami Konsep (Understand the Concept)}

Understanding the material in a lesson is good, but able to corelate it in the real live is better. This strategy emphasizes students' understanding to learn materials better. The data shown that the teachers used variety method to apply it. They are:

\section{Data $03 / 2$}

"Menyusun materi pembelajaran berdasarkan konsep. Melalui ilustrasi gambar atau video, siswa dapat memahami konsep suatu materi. Sehingga dalam proses menyelesaikan masalah, tidak berdasarkan hafalan, tetapi pemahaman konsep siswa terhadap materi".

[Arranging learning materials based on concepts. Through picture or video illustrations, students can understand the concept of a material. So that in the process of solving problems, it is not based on memorization, but students' understanding of the concept of the material].

Giving understanding to students about the content of the material taught and giving example in the application to make students easier to understand and feel the lesson is important to them. Another example shown similar action, as follows:

\section{Data $06 / 2$}

"Memberikan pemahaman kepada murid akan belajar suatu konsep, tidak hanya mempelajari suatu konten"

[Providing understanding to students of learning a concept, not just learning a content]

This second strategy brought the Concept-based instruction in learning which is driven by "big ideas" rather than subject-specific content. Students are leading to consider the context to use their understanding, concept-based learning brought "real world" meaning to content knowledge and skills. Students become critical thinkers which is essential to their ability to creatively solve problems in the 21st century (Erickson, 2008).

\section{c. Membangun Keberlanjutan (Building Sustainability)}

This strategy guide students to experience the directed learning. By giving feedback and respons to the students works increase students' understanding and development thinking. These method were applied by teachers as follow: Data $05 / 3$

"Sesudah memberikan tugas / ulangan memberikan feedback secara personal. Kemudian menggunakan feedback tersebut untuk meningkatkan pemahaman murid."

[After giving assignments / tests, give personal feedback. Then use this feedback to improve students' understanding.]

Data $03 / 3$

"Memberikan umpan balik pada tugas tugas yang diberikan ke murid."

[Provide feedback on assignments given to students]

Data $04 / 3$ 
"Memberikan umpan balik terhadap proses pembelajaran yang telah dilalui siswa dan tugas yang dikerjakan oleh siswa. Sehingga siswa tau apa yang harus diperbaiki agar proses pembelajaran dan tugas lebih baik"

[Provide feedback on the learning process that students have gone through and the assignments done by students. So that students know what needs to be improved so that the learning process and better assignments]

d. Memilih Tantangan (Choosing a Challenge)

This strategy concerns in giving flexibility and freedom to students in choosing the method, media, and the way they want to learn and doing assignments. By giving the right for choosing their own favourite way in learning, they can maximize their understanding in doing distance learning. Such method were applied by teachers as follow:

Data $10 / 4$

"saya memberikan keleluasaan bagi murid untuk mengerjakan tugas sesuai kebutuhan dan minatnya...."

[I provide flexibility for students to do assignments according to their needs and interests...]

Data $12 / 4$

Murid diberikan pilihan pengerjaan tugas bisa menggunakan infografis, video, atau audio

[Students are given the choice of how to do assignments using infographics, video, or audio]

Data $07 / 4$

Memberikan keleluasaan kepada murid dalam pembelajaran dan tugas. Murid bisa memilih tugas sesuai kemampuannya. Misal dengan gambar, tulisan atau voice notes.

[Provide flexibility to students in learning and doing assignments. Students can choose tasks according to their abilities. For example, with pictures, writing or voice notes.]

\section{e. Memberdayakan Konteks (Empowering Context)}

This is the most dominant strategy applied by teachers. This strategy combined the learning material into students' environment with the purpose to maximize students understanding and active respons in teaching learning activity. Some of the teachers' answers are follow:

Data $11 / 5$

"Mengajak anak menulis review di travel online yang memberdayakan penggunaan teknologi smartphone."

[Inviting students to write a review in the travel online application which empowering the use of smartphone technology]

Data $07 / 5$

"Menyiapkan menu bersama keluarga kemudian mempresentasikannya dengan gambar/bentuk lain yang dipilih menggunakan bahasa Inggris."

[Preparing the menu with the family then present it with pictures / other shapes that are selected in English.]

Data $14 / 5$

"mengajak murid untuk memanfaatkan sumberdaya yang ada di sekitar sebagai sumber belajar"

[inviting students to take advantage of existing resources as a learning resource] 
From the findings, it can be seen that the application of 5M strategy in distance learning activities can maximize the relationship of the teachers, students and parents better. This aspect gave better effect in the process of distance learning activities during Covid-19 pandemic. Leontyeva (2018) also supported that distance learning development were affected by parents-teachers' unreadiness, inadequate references, unsuitable managerial structure and inefficient facilities in the process of learning. Noor, S., Isa, F.M., (2020) proved that both students and teachers encountered many barriers during online learning in Covid-19 pandemic period. The challenges occurred during online learning were devided into three types, technology-related, teachers-related and students-related challenges (Noor, S., Isa, F.M., 2020). This 5M strategy helps teacher to do the distance learning process condusively and effectively by maximizing all sector to support the condition in teaching learning process.

\section{CONCLUSION}

Distance learning of ELT during covid-19 pandemic faced many barrier in its process. 5M strategy gave clear understanding and strategy to maximize the relationship between teachers, students, and parents in order to get the essential teaching learning activity. Based on the findings, it can be seen that teachers are able to apply most of the 5M strategy to maintain and develop their teaching learning activity be more lively and actively. The engangement of the students is the main issue which should be considered by teachers in doing distance learning activity. This study also reveal some facts that teacher applied some interesting methods in representing 5M strategy such as doing Diagnostic Assessment and Concept Based Learning (CBL) in their learning.

\section{REFERENCES}

Abidin, Z., Hudaya, A., \& Anjani, D. (2020). Efektivitas Pembelajaran Jarak Jauh Pada Masa Pandemi Covid-19. Research and Development Journal of Education, 1(2), 131-146.

Aditama, M G., Dwi Haryanti, Musiman, Fitria Wulan, S. (2020). The Advantages of Personal Documentation Video in Improving Students' Speaking Skill for Presentation. Proceedings of the 5th Progressive and Fun Education International Conference (PFEIC 2020). https://doi.org/https://doi.org/10.2991/assehr.k.201015.014

Aditama, M G. \& Sugiharto, P. A. (2021). Improving Students' English Pronunciation by Using Hypermedia in E-Learning Activity. Edukasia: Jurnal Pendidikan Dan Pembelajaran, 2(1), 117-126.

Basar, A. M. (2021). Problematika Pembelajaran Jarak Jauh Pada Masa Pandemi Covid-19 (Studi Kasus di SMPIT Nurul Fajri - Cikarang Barat - Bekasi). Edunesia : Jurnal Ilmiah Pendidikan, 2(1). 
Erickson, H. L. (2008). Stirring the Head, Heart and Soul: Redefining Curriculum and Instruction. (3rd ed.). Corwin Press.

Finch, D., \& Jacobs, K. (2012). Online education: Best practices to promote learning. Proceedings of the Human Factors and Ergonomics 56th Annual Meeting.

Firman, \& Rahayu, S. (2020). Pembelajaran Online di Tengah Pandemi Covid-19. Indonesian Journal of Educational Science (IJES), 2(2), 81-89. https://doi.org/https://doi.org/10.31605/ijes.v2i2.659

Karwati, E. (2014). Pengaruh Pembelajaran elektronik (e-learning) terhadap mutu belajar mahasiswa. Jurnal Penelitian Komunikasi, 17(1), 41-54.

Laeli, A. F., \& Oktarini, W. (2021). VOA video adopted instruction: An attempt to engage EFL students' active participation in listening activities. Research and Innovation in Language Learning, 4(1), 18-30.

Lee, Y. W., \& Sawaki, Y. (2009). ognitive diagnosis approaches to language assessment: an overview. Language Assessment Quarterly, 6(3), 172-189.

Lee, Y. W. (2015). Diagnosing diagnostic language assessment. Language Testing, $32(3), 299-316$.

Leontyeva, I. A. (2018). Modern distance learning technologies in higher education: introduction problems. EURASIA Journal of Mathematics, Science and Technology, 4(10), 1-8.

Mendikbud RI. (2020). Surat Edaran Nomor 4 Tahun 2020 Tentang Pelaksanaan Kebijakan Pendidikan Dalam Masa Darurat Penyebaran Coronavirus Disease (COVID-19).

Moore, M., \& Kearsley, G. (2012). Distance education: A systems view of online learning. In Educational Process International Journal. CA: Wadsworth. https://doi.org/1

Noor, S., Isa, F.M., \& M. F. . (2020). Online teaching practices during the Covid-19 pandemic. Educational Process International Journal, 9(3), 169-184. https://doi.org/10.22521/edupij.2020.93.4

Pakpahan, R. \& Fitriani, Y. (2020). Analisa Pemanfaatan Teknologi Informasi dalam Pembelajaran Jarak Jauh di Tengah Pandemi Virus Corona Covid-19. JISAMAR (Journal of Information System, Applied, Management, Accounting and Researh.

Pramana, Cipta., et al. (2021). Distance Learning in Primary Schools During The Covid-19 Pandemic in Indonesia: Challenges, Solutions, and Projections. Turkish Journal of Computer and Mathematics Education., 12 (4 (2021)), 263270.

Prawiyogi, A G, et al. (2020). Efektifitas Pembelajaran Jarak Jauh Terhadap Pembelajaran Siswa di SDIT Cendekia Purwakarta. JPD: Jurnal Pendidikan Dasar. https://doi.org/doi.org/10.21009/JPD.011.10

Rusman, Kurniawan, D., \& Riyana, C. (2013). Pembelajaran Berbasis Teknologi Informasi dan Komunikasi: Mengembangkan Profesionalitas Guru. Rajawali Pers.

Rusmiati, A. R., Reza, R., Achmad, S., Syaodih, E., Nurtanto, M., Sultan, A., Riana, A., \& Tambunan, S. (2020). The perceptions of primary school teachers of online learning during the COVID-19 pandemic period: A Case study in Indonesia. Journal of Ethnic and Cultural Studies, 7(2), 90-109.

Shihab, N. \& K. G. B. (2018). Memanusiakan Hubungan. Literasi.

Tîrziu, A. M., \& Vrabie, C. (2015). Education 2.0: E-learning methods. Procedia-Social 
and Behavioral Sciences, 186, 376-380. https://doi.org/https://doi.org/10.1016/j.sbspro.2015.04.213

Zaharah, Z., \& Kirilova, G. I. (2020). Impact of Corona Virus Outbreak Towards Teaching and Learning Activities in Indonesia. SALAM: Jurnal Sosial Dan Budaya Syar-I, 7(3). https://doi.org/https://doi.org/10.15408/sjsbs.v7i3.15104

Zaw, E. M. (2019). Creating Positive English Language Learning Environment through Communicative Language Teaching. 2nd International Conference on Engineering Education and Innovation. 